\title{
Effect of Mineralogy on Durability and Strength of Hornfelsic Rocks under Acidic Rainfall in Urban Areas
}

\author{
Ghobadi M.H.; Geology Department, Bu-Ali Sina \\ University, Hamedan, Iran \\ D. Fereidooni; Earth Science School, Damghan University, \\ Damghan, Iran
}

Received: 27 Juan 2013

Revised: 8 Sep 2013

\begin{abstract}
In order to assess mineralogical composition influence on durability and strength of rocks, four samples of hornfelsic rocks were selected from southern and western parts of the city of Hamedan, west of Iran. These rock samples were subjected to mineralogical, physical and mechanical tests in the laboratory. Also, they were evaluated in 15 cycles of slake-durability testing in different $\mathrm{pH}$ of sulfuric acid solutions and XRD analysis. Based on the results, the type and amount of minerals, their density and hardness had an influence on the uniaxial compressive strength and the slake durability index of tested rocks. That means, presence of non-dissolved minerals such as graphite in studied rocks, decreases Unconfined Compressing Strength (UCS) but increases the slake durability index. The results of slake-durability test indicated that weight loss of the samples at initial cycles was found to be higher than the end cycles. Also, in these samples, initial minerals in the fresh samples were not exchanged by secondary minerals such as clay minerals. Therefore Hamedan hornfelsic rocks are approximately resistant when were put under accelerated chemical weathering and degradation in the laboratory and natural chemical weathering.
\end{abstract}

Keywords: Hornfels, Durability, pH, XRD, Weathering amirghobadi@yahoo.com 


\section{Introduction}

Perhaps one of the major problems for application of different rocks as construction materials and foundation purposes is their susceptibility to degradation or chemical weathering. Weathering is an important geological and engineering geological process resulting in a change in the physical and chemical properties of unweathered rocks once they are exposed to air (Oyama and Chigira, 1999). In other words, weathering can induce a rapid change of rock material from initial properties to soil-like properties. This means that natural weathering processes can lead to the transformation of primary minerals into secondary crystalline and amorphous products (Schiavon, 2007). Therefore, the weathering process is divided into physical and chemical types according to the changes of the rock's mineralogical compositions. According to Topal and Sozmen (2003), chemical weathering of rocks may cause changes in initial elemental concentrations by leaching and enrichment. Rainfall and availability of water, apart from temperature, are the important factors that influence the intensity of chemical weathering (Sajinkumar et al. 2011). In addition, other environmental factors such as Hydrosphere, topographical and climatic conditions have an important effect on the weathering process of rock materials (Erguler, 2009).

The sensitivity of a rock type against weatherability and the rate of occurrence of such a change can be descripted by a durability parameter, such as the slake-durability index (Ulusay and Sonmez, 
2000). The degradation and weathering of rocks are extensive especially in rocks placed in areas where they are subjected to constant wetting and drying (Yavuz, 2006) and where air pollution is heavy. Also, the rate and nature of chemical weathering is governed by many variables such as parent-rock type, topography, leaching conditions and biological activities (Lee et al. 2008).

Recent urban development and industrialization of cities have changed most environmental conditions. Atmospheric pollutions and the increase in $\mathrm{SO}_{2}$ and $\mathrm{NO}_{\mathrm{x}}$ gases can be the result of the rise in fossil fuel combustion. These gases combined with water present in the atmosphere will cause a reaction which is rainfall $\mathrm{pH}$ occasionally dropping to below 5 values. Furthermore, the produced sulfuric and nitric acid solutions are important agents in degradation of ancient building stones especially those with carbonate minerals (Ghobadi and Momeni, 2011).

An increasing use of hornfelsic rocks as construction stones has highlighted the importance of these materials as an engineering resource. These rocks were used as foundation, kerb, pavement and facade stones on a various engineering projects. Hornfelsic rocks generally have high strength, but when using these rocks as construction materials, the most important aspect to be considered is their degradation mechanism and chemical weathering potential.

Hamedan is one of the most important cities of Iran where hornfelsic rocks have had a presence due to the injection of Alvand 
batholiths into Hamedan Jurassic schists. Recent developments and industrialization of this city has caused air pollution and acidic rainfalls which have resulted in weathering of different rocks. In this research, we simulated natural conditions in the laboratory and are attempted to report the deterioration and weathering mechanism of hornfelsic rocks in this region.

\section{Site description and geology}

In order to determine the effect of acidic rainfalls on weathering and degradation mechanism of the hornfelsic rocks, the southern and western parts of the city of Hamedan were selected as the study area (Figure 1). This region has an irregular morphology related to its geological history, tectonics and lithology. The geological conditions of the study area, with a longitude of $48^{\circ} 10^{\prime} \mathrm{E}$ to $48^{\circ} 35^{\prime} \mathrm{E}$ and a latitude of $34^{\circ} 30^{\prime} \mathrm{N}$ to $34^{\circ} 52^{\prime} \mathrm{N}$, is one of the most important and interesting plutonic rock masses with its metamorphic aureole rocks in the earth crust of Iran. This granitic rock mass, called Alvand, is bordered from north and east to Hamedan, from south to Touyserkan and from north-west to Assad-Abad. It covers an area of about 400 $\mathrm{km}^{2}$ which makes the largest plutonic rock mass in Iran.

The metamorphic rocks around this granitic rock mass are pelitic hornfelic rocks such as garnet hornfels, sillimanite hornfels, kyanite hornfels and starlite hornfels. The geology deposits, closing the north and east side of the study area, are the quaternary alluvial. The study area has an elevation of $1950 \mathrm{~m}$ above sea level and it_has typical 
continental climate. Summers are warm and dry, whereas winters are cold with high snowfalls, and springs are rainy.

Sampling locations were Heydareh village (HYD), Abbas-Abad valley (ABS), Cheshmeh-Malek village (CMM) and Faghireh village (FAG) in the vicinity of Hamedan which are shown on the geological map of the region.

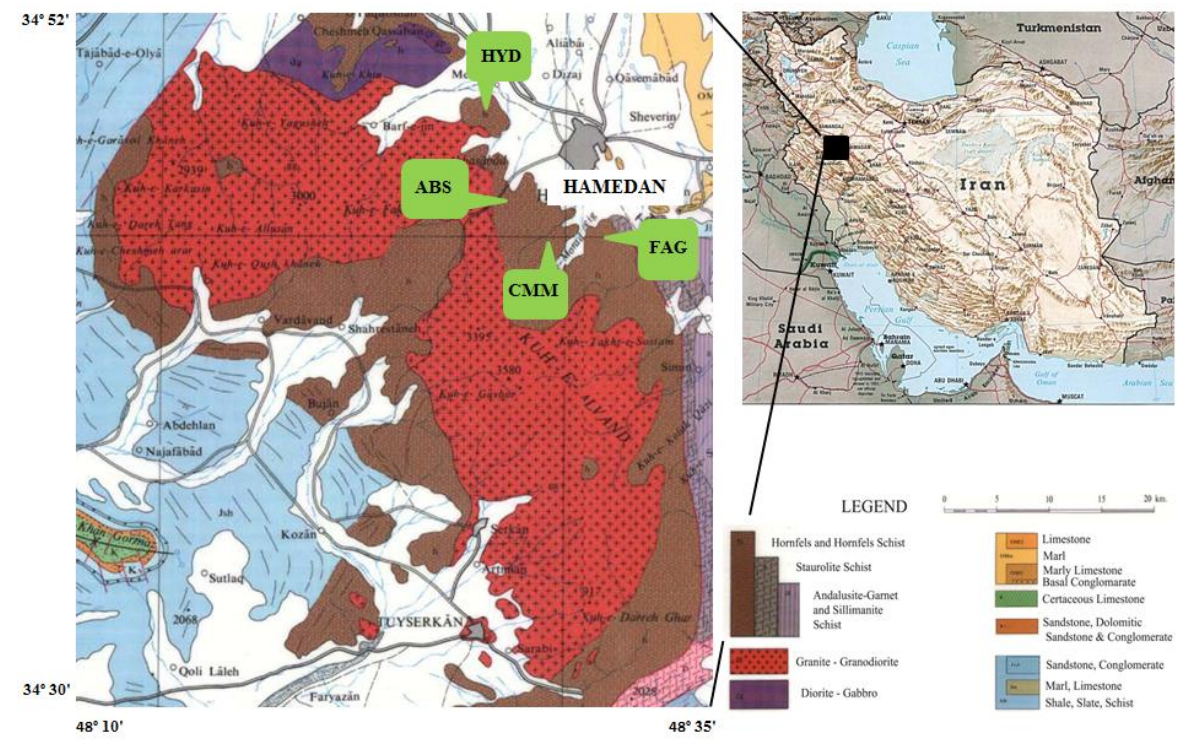

Figure1. Geological map of the study area and location of sampling

\section{Methods and materials}

In this research, the used samples were hornfelsic rocks collected from the southern and western parts of the city of Hamedan. These locations were Heydareh (HYD), Abbas-Abad (ABS), CheshmehMalek (CMM) and Faghireh (FAG). During the field investigation lithological and structural characteristics of the hornfelses were 
determined and sampling was done in the site of road cuttings or foundation excavations.

Degradation mechanisms and strength parameters of the hornfelsic rocks affected by acidic rainfalls were investigated through physical and mechanical properties (density, water absorption, porosity, $\mathrm{P}$ wave velocity and UCS), optical microscopy, X-ray diffractometry (XRD) and some index parameters. Accelerated weathering tests such as wetting-drying was performed, and durability assessment methods were used to predict the durability of the hornfelsic rocks at 15 cycles in natural water and sulfuric acid solutions with different $\mathrm{pH}$.

Polished thin sections were prepared for optical microscopic observations to identify the mineral composition and texture of the rock samples. XRD analysis was performed for fresh rocks and cycle powders as well as clay fractions $(<2 \mathrm{~mm}$ in size $)$ separated from rock powders. The powdered rock samples were radiated to determine their mineral composition.

\section{Results}

The hornfelsic rock samples were tested under laboratory conditions and their different properties were estimated as follows:

\section{Petrographical and Mineralogical properties}

Standard petrographic thin sections were prepared from the rock block samples. The mineralogical study of the thin sections showed that the pelitic hornfelic rocks were commonly composed of quartz, biotite, muscovite, garnet, sillimanite, kyanite, Staurolite, graphite and 
other fine cryptocrystalline matrix materials. Garnet, sillimanite, kyanite, Staurolite and graphite crystallize in metamorphic conditions. The composition and texture of the rocks were porphyroblastic pelitic hornfels. Therefore, the rock textures could be divided into two components: porphyroblasts and matrix. Garnet, Kyanite, Staurolite and Sillimanite porphyroblasts were the dominant types, ranging in size from 0.5 to $2 \mathrm{~mm}$ (Figure 2). The matrix was characterized by $100-\mu \mathrm{m}$-wide minerals of quartz, biotite and muscovite $(50-100 \mu \mathrm{m}$ dimensions). This pattern defined a fabric characteristic of contact metamorphic rocks. The quartz in the matrix of the rocks was generally less than $70 \mu \mathrm{m}$ in any dimension and did not exhibit well defined grain boundaries with either white mica or other quartz grains. Graphite occurred at a 400- $\mu \mathrm{m}$-length, distributing throughout the matrix in CMM sample. Table 1 is a summary of the modal abundance of the minerals and Figure 2 shows macroscopic and microscopic fabric images of the hornfels in the study area that also indicate Mineral composition of the rock samples.

Table1. Mineral composition of the rock samples

\begin{tabular}{|c|c|c|c|c|c|c|c|c|c|}
\hline \multirow{2}{*}{$\begin{array}{l}\text { Rock } \\
\text { mark }\end{array}$} & \multirow{2}{*}{$\begin{array}{l}\text { Rock } \\
\text { type }\end{array}$} & \multicolumn{8}{|c|}{ Minerals contents $(\%)$} \\
\hline & & Qtz. & Bt. & Mt. & Gt. & Slt. & Kt. & St. & Gpht. \\
\hline HYD & Hornfels & 35 & 30 & 5 & 10 & 20 & - & - & - \\
\hline ABS & Hornfels & 32 & 20 & 8 & 15 & 5 & 15 & 5 & - \\
\hline CMM & Hornfels & 25 & 25 & 5 & 15 & - & - & - & 30 \\
\hline FAG & Hornfels & 40 & 25 & 11 & 11 & - & 7 & 5 & - \\
\hline
\end{tabular}

Qtz. Quartz, Bt. Biotite, Mt. Muscovite, Gt. Garnet, Sit. Sillimanite,

Kt. Kyanite, St. Staurolite, Gpht. Graphite 

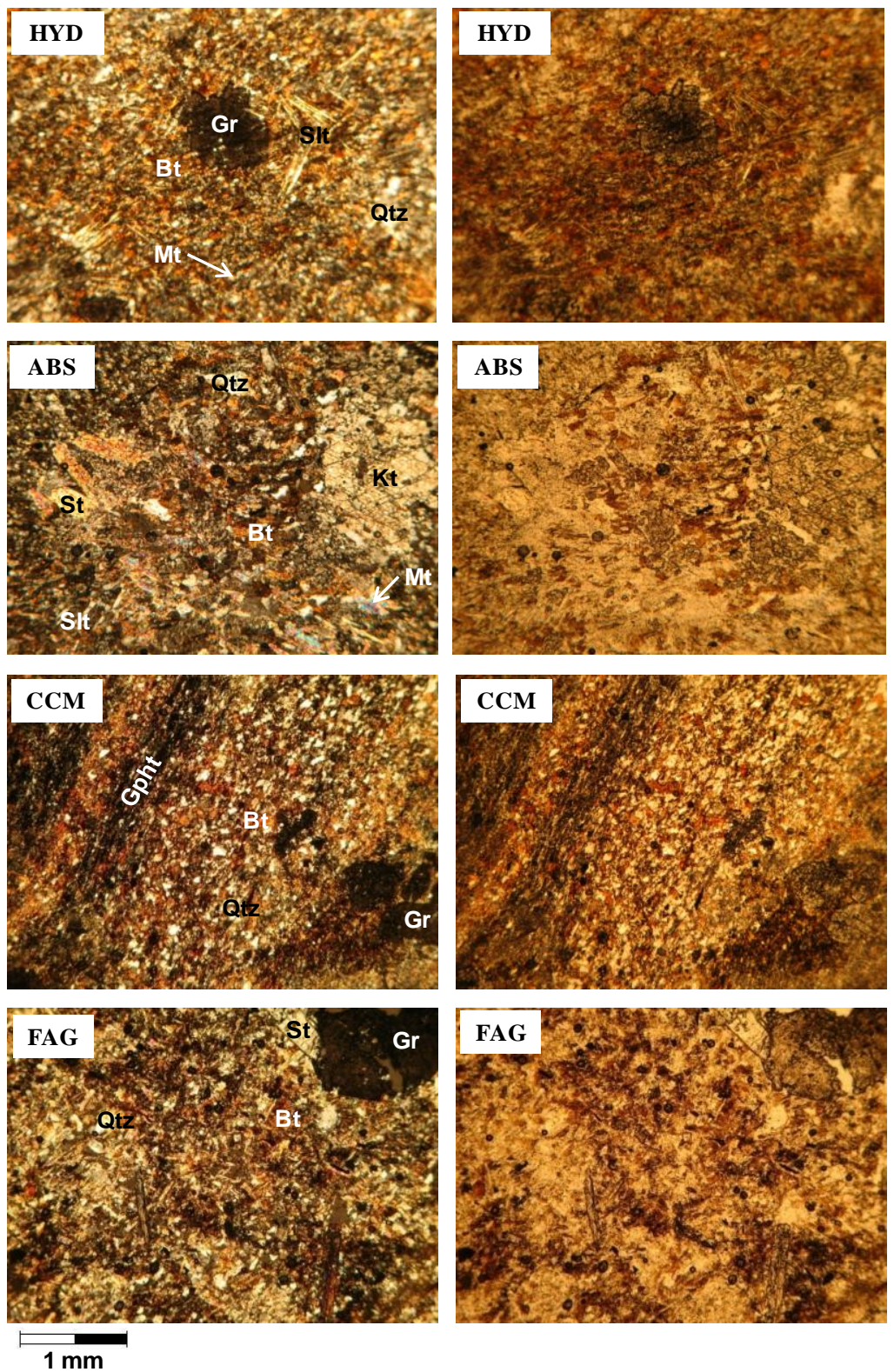

Figure2. Microscopic fabric images of the various tested rock samples (The left images are in polarized light and the right images are in normalized light) 


\section{Physical and mechanical properties}

Physical properties of the rock samples, namely dry and saturated unit weights $\left(\gamma_{\mathrm{d}}\right.$ and $\left.\gamma_{\mathrm{sat}}\right)$, water absorption $\left(\mathrm{W}_{\mathrm{a}}\right)$, porosity $(\mathrm{n})$, void ratio (e) and specific gravity $\left(\mathrm{G}_{\mathrm{s}}\right)$ were also determined using the standard testing methods suggested by the International Society for Rock Mechanics (ISRM, 1981). For this purpose, the block samples that were taken during the field investigation were used and five sets of experiments were performed on each rock sample. Also, Schmidt hardness and P-wave velocity of the samples were calculated for all of the samples. In this research, uniaxial compressive strength values were determined from Schmidt hammer results. Table 2 and table 3 show average values of the mentioned parameters for different tested samples.

Table2. Physical properties of tested samples

\begin{tabular}{ccccccc}
\hline Sample & $\gamma_{\mathrm{d}}\left(\mathrm{gr} / \mathrm{cm}^{3}\right)$ & $\begin{array}{c}\gamma_{\text {sat }} \\
\left(\mathrm{gr} / \mathrm{cm}^{3}\right)\end{array}$ & $\mathrm{W}_{\mathrm{a}}(\%)$ & $\mathrm{n}(\%)$ & $\mathrm{e}$ & $\mathrm{G}_{\mathrm{s}}$ \\
\hline HYD & 2.85 & 2.87 & 0.70 & 2.00 & 0.02 & 2.90 \\
ABS & 2.85 & 2.86 & 0.32 & 0.92 & 0.01 & 2.87 \\
CMM & 2.81 & 2.82 & 0.35 & 0.97 & 0.01 & 2.84 \\
FAG & 2.78 & 2.81 & 1.00 & 2.78 & 0.03 & 2.86 \\
\hline
\end{tabular}

Table3. Index and mechanical properties of tested samples

\begin{tabular}{cccc}
\hline Sample & $\mathrm{H}_{\mathrm{s}}$ & $\mathrm{V}_{\mathrm{p}}(\mathrm{m} / \mathrm{s})$ & UCS $(\mathrm{MPa})$ \\
\hline HYD & 40 & 5529 & 77.67 \\
ABS & 49 & 5065 & 123.12 \\
CMM & 45 & 5225 & 98.61 \\
FAG & 41 & 3912 & 75.34 \\
\hline
\end{tabular}

According to Bell (2000) the samples of HYD, ABS and CMM are fresh, because their wave velocity is higher than $5000 \mathrm{~m} / \mathrm{s}$. whereas, 
the sample of FAG is moderately weathered, because its wave velocity is between $3000-4000 \mathrm{~m} / \mathrm{s}$ range.

\section{Slake-durability test}

It is well known that slake-durability of rocks is an important consideration in evaluating the engineering behavior of rock-masses and rock-materials in geotechnical practices (Franklin and Chandra, 1971; Rodrigues, 1991; Dick and Shakoor, 1995; Gokceoglu et al. 2000; Dhakal et al. 2002). The durability of a stone is a measure of its ability to resist weathering and so to retain its original size, shape, strength, and appearance over an extensive period of time (Sims, 1991; Bell, 1993). This property represents the degradability of rocks due to the process of chemical and mechanical breakdown as in exfoliation, hydration, solution, oxidation, and abrasion (Gupta and Ahmed, 2007) and it is closely related to the mineralogical composition of rocks.

This test was carried out for the samples using the standard testing method developed by Franklin and Chandra (1971) recommended by ISRM (1981) and standardized by ASTM (1990). To perform the test, rock lumps (10 pieces of about 40-60 g each) (Figure 3) were prepared and rotated for $10 \mathrm{~min}$ in a test drum made of a standard sieve mesh so that the products of slaking were finer than $2 \mathrm{~mm}$ and could pass through the drum into the water bath. The drum was half immersed in a slaking solution bath at $20^{\circ} \mathrm{C}$. The slake durability index (Id) corresponding to each cycle was calculated as the percentage ratio of 
final to initial dry weights of rock in the drum after the drying and wetting cycles.

In most studies carried out by different researchers, the assessment of durability is based on the second-cycle slake durability index. However, some researchers such as Bell et al. (1997) and Gokceoglu et al. (2000) emphasized that two-cycle slake durability testing did not appear to offer an acceptable indication of rocks. In this research, in order to understand the effect of acidic solutions on degradability of Hamedan hornfelsic rocks, the slake durability test was carried out on four types of rocks up to 15 cycles in different $\mathrm{pH}$ conditions. The used slaking solutions were natural water with $\mathrm{pH}=7$ of the region and sulfuric acidic solutions with $\mathrm{pH}=2,4$ and 5.5 prepared in the laboratory. After the slake durability test was carried out for the samples, the related curves were drown. Figure 4 shows the effects of the wetting-drying cycles on variation of weight loss of the samples in different $\mathrm{pH}$ conditions. It should be noted that with an increase in the number of cycles, the rate of the weight loss decreases for all samples. Maximum weight loss was obtained from the FAG sample whereas its minimum was detected in the CMM sample. The influence of the number of slaking cycles on slake durability index in different $\mathrm{pH}$ conditions is shown in Figure 5. Similar to weight loss, the decrease rate of durability index at the initial cycles is higher than the end cycles. Figure 6 shows a comparative diagram of slake durability index for cycle 15 in different $\mathrm{pH}$ conditions. Based on this figure after cycle 15 , 

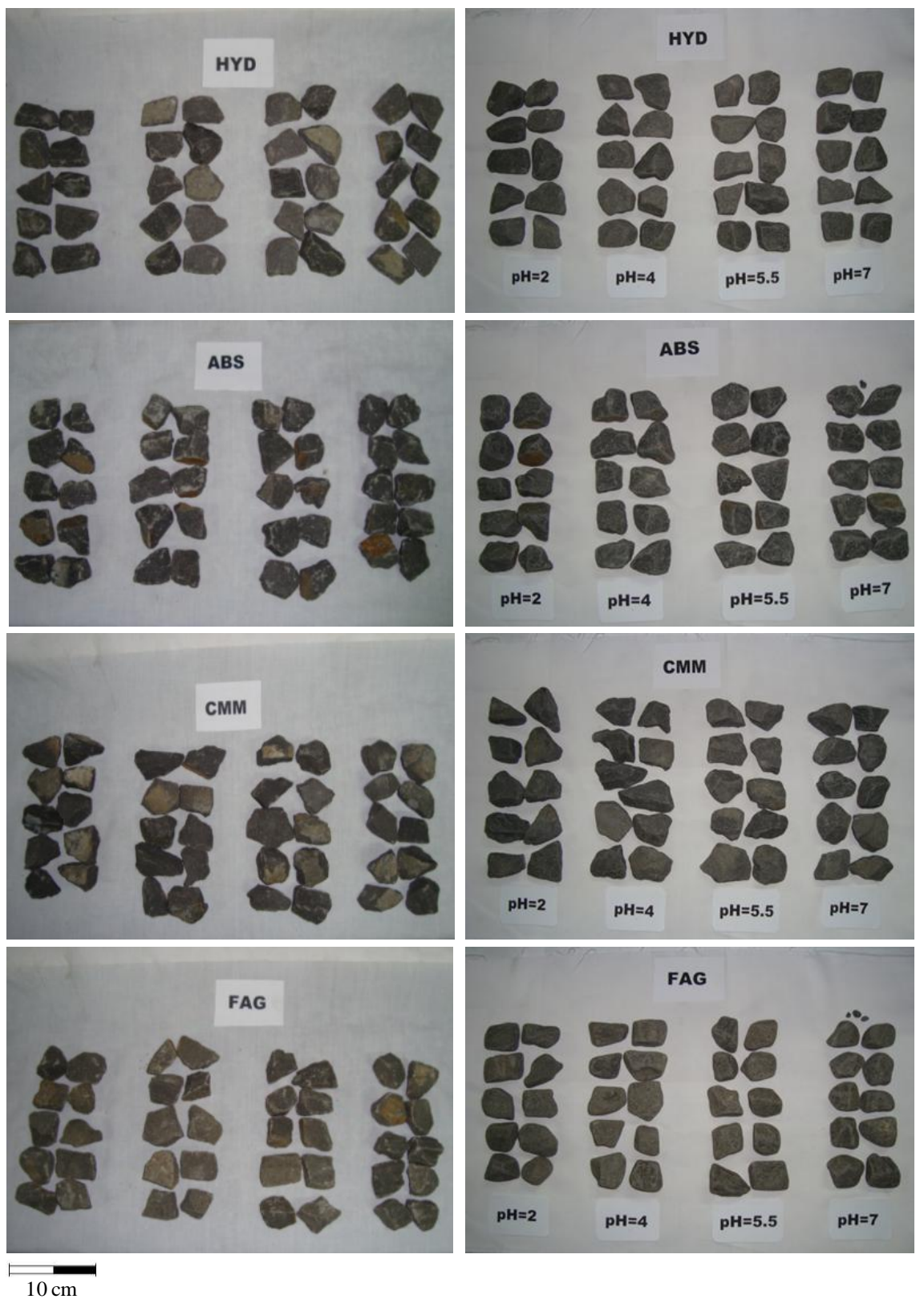

Figure3. Prepared rock lumps before slake durability test (left) and after cycle 15 (right) 
maximum durability index obtained from the CMM sample compared to the FAG sample which indicated the minimum durability index. HYD and ABS samples have a middle range of durability index.
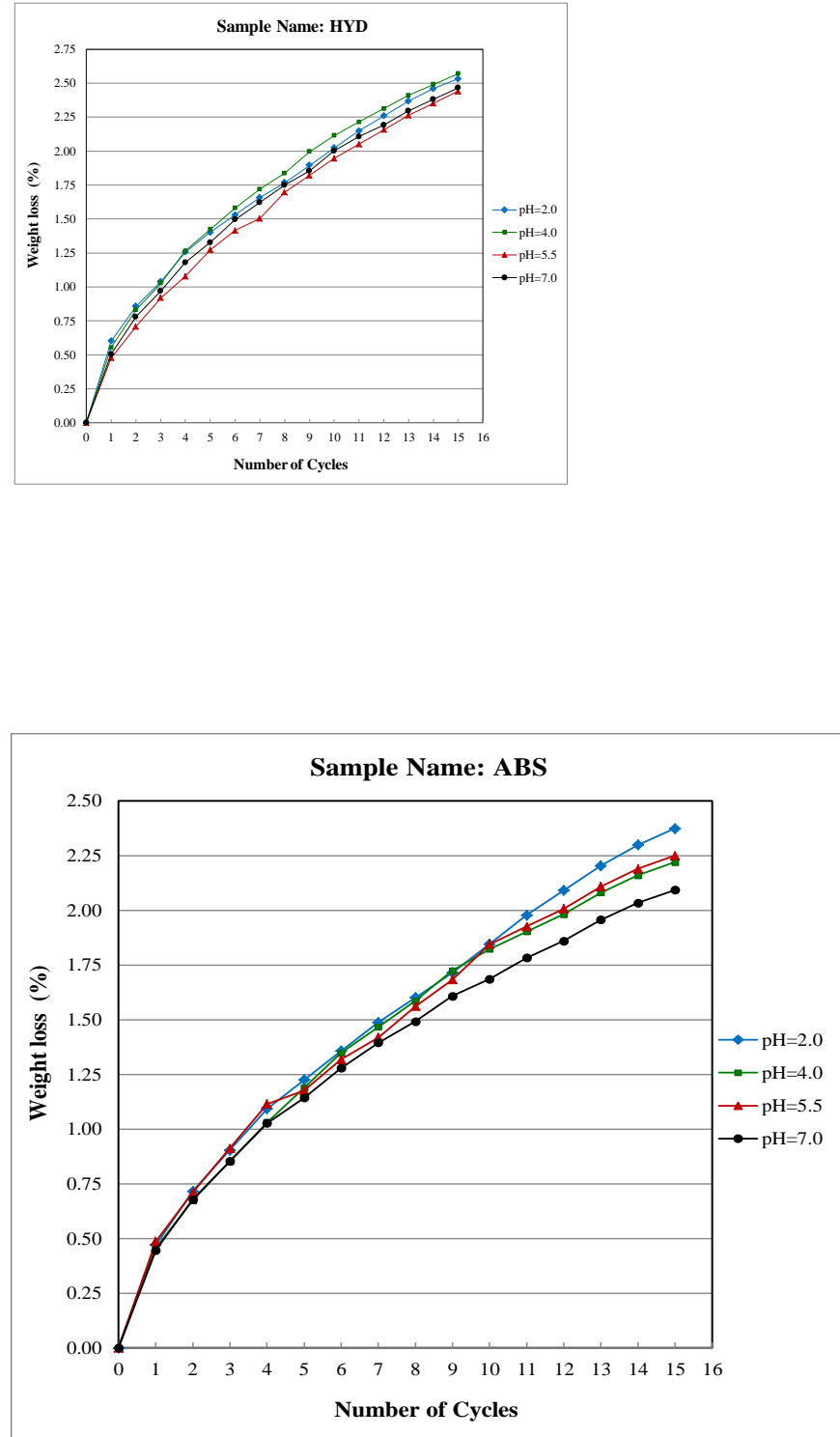

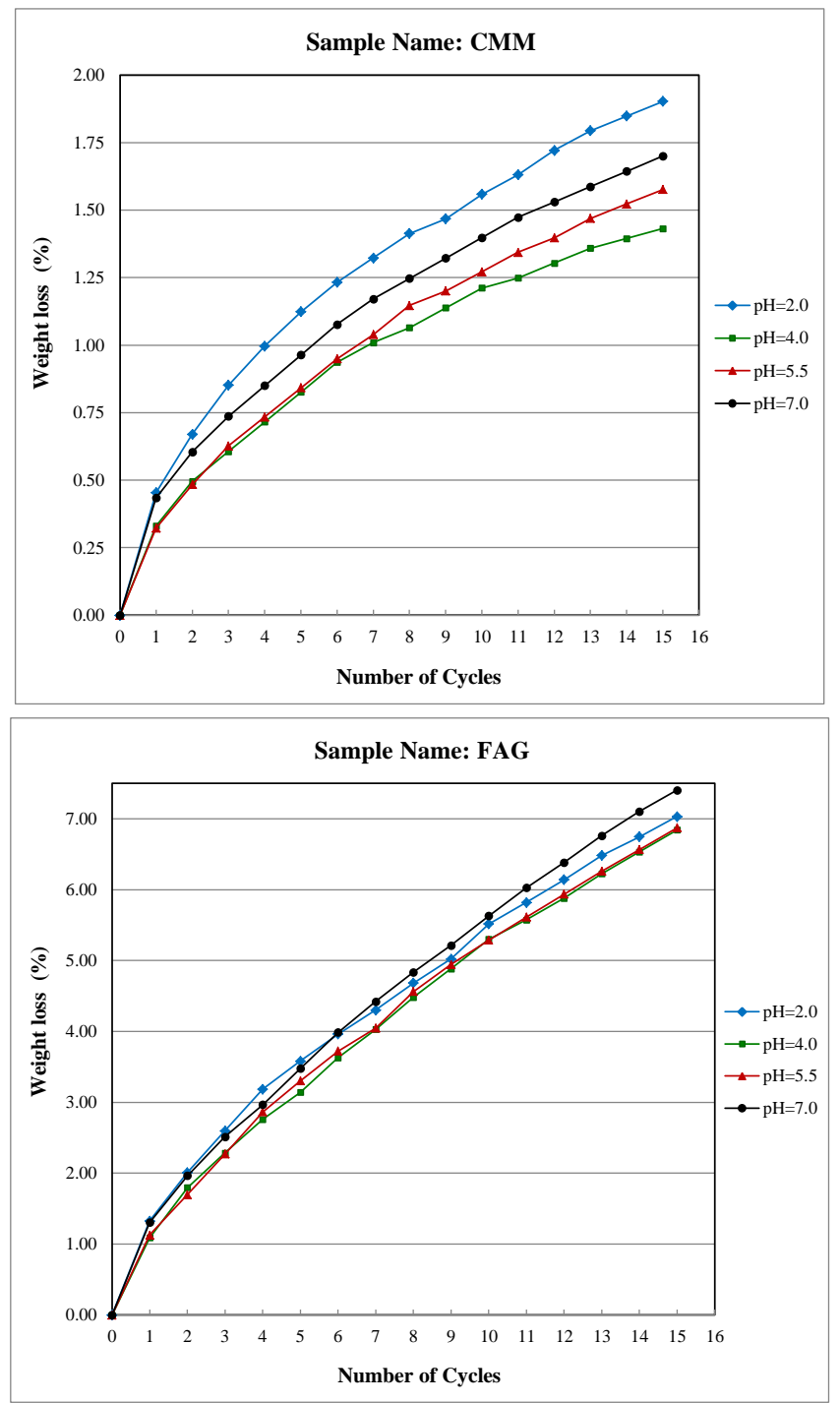

Figure4. The effect of wetting-drying cycles on variation of weight loss of the samples 


\section{XRD results}

$\mathrm{X}$-ray diffraction (XRD) analysis was conducted and compositions of the samples were determined in the $2 \theta$ range of $2^{\circ}$ to $60^{\circ}$. The degree of quartz crystallinity was evaluated in the $2 \theta$ range of $25^{\circ}$ to $28^{\circ}$. The mineral composition of the fresh rocks and other samples under the durability test were fairly similar. The results contain a large amount of quartz and Illite-Mica and a small amount of metamorphic minerals such as Garnet, Sillimanite, Kyanite and Graphite representing the matrix fraction of the rock for all samples. The diffractograms for each sample were different only in the intensity of the peaks, but they didn't indicate an increase and/or a decrease trend. This means that $\mathrm{pH}$ had no effect on chemical weathering of the rock's minerals. The diffractograms of fresh rocks of ABS samples after cycle number 2 are selected as an example and are shown in Figure 7.

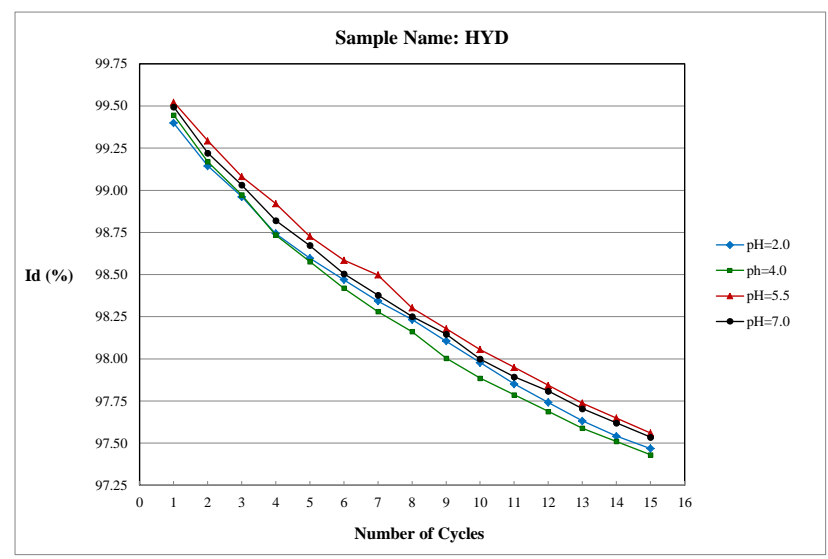



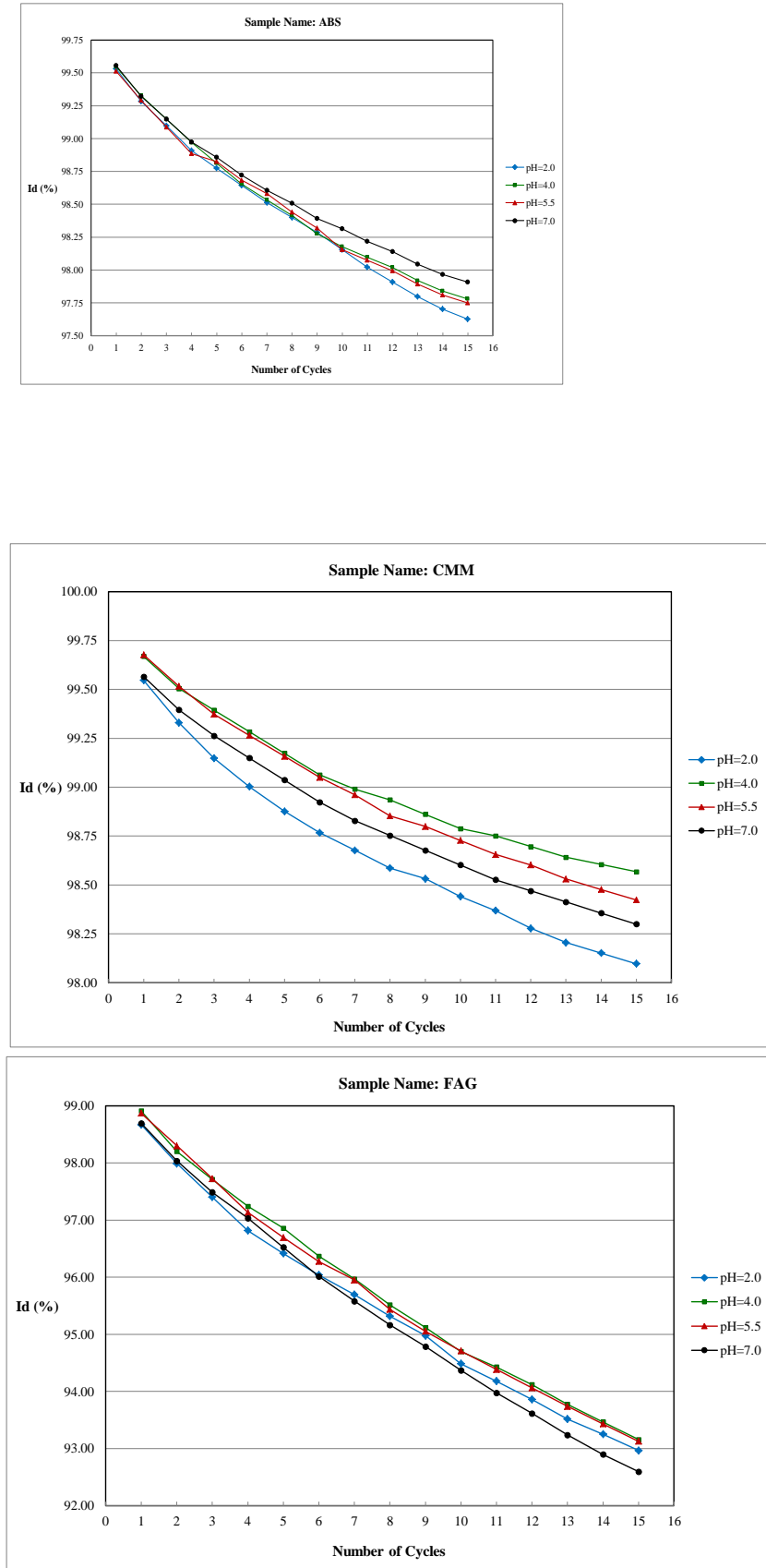

Figure5. Influence of the number of slaking cycles on slake durability index in different $\mathrm{pH}$ conditions 


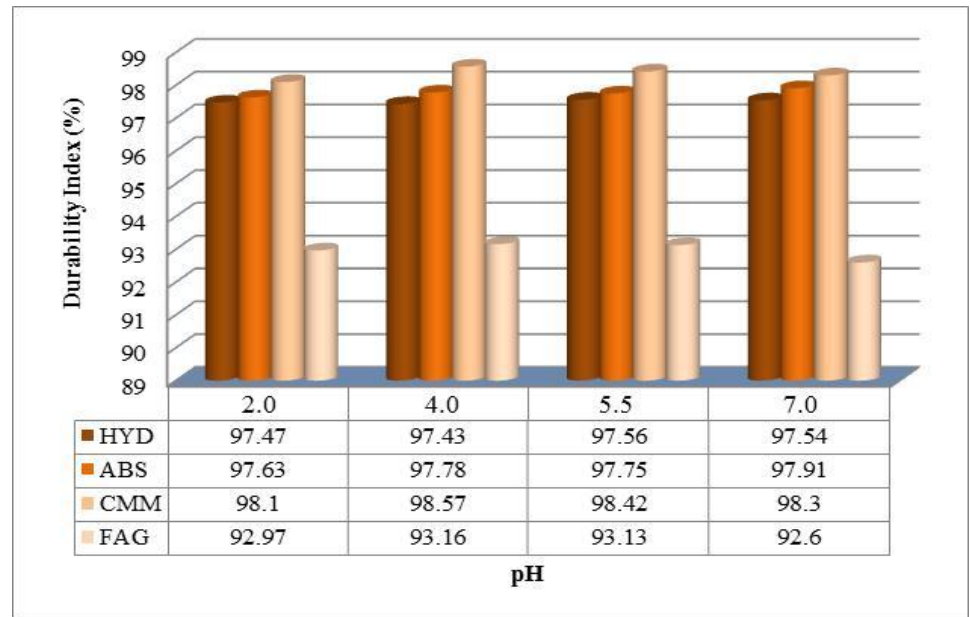

Figure6. Comparative diagram of slake durability index for cycle 15 in different $\mathrm{pH}$ conditions

\section{Discussion}

In this research, mineralogical examinations and slake-durability tests for hornfelsic rocks from Hamedan were performed in order to assess the slake-durability and rock weathering process of these rocks as well as to understand the relationship between mineralogy, durability and strength. The assessment of physical and mineralogical properties of the samples showed that some properties such as specific gravity and density are affected by the mineral composition of the rocks. Metamorphic minerals such as garnet are durable and have greater density. Therefore this property increases rock density and durability. On the other hand, increase in quartz content decreases rock durability because this mineral has high hardness. This property causes abrasion of the rock samples during the slake-durability test and decreases the 


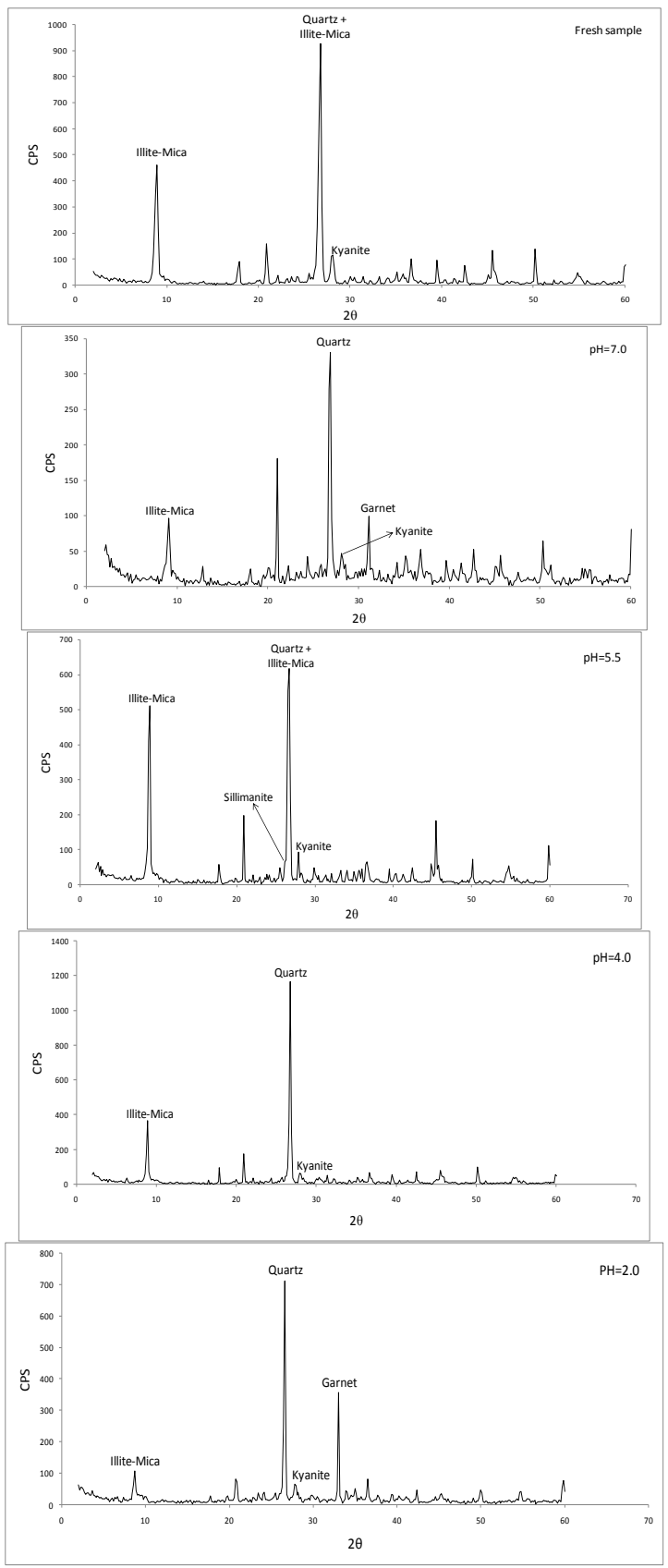

Figure7. Diffractograms of ABS fresh sample and samples under slakedurability test at different $\mathrm{pH}$ 
slake-durability_index. Some properties such as water absorption are affected by porosity. Every increase in the value of porosity decreases the rock durability. For example the FAG sample has a minimum dry density and a maximum porosity, therefore, it has the lowest durability among all samples.

HYD, ABS and CMM samples are fresh, because their wave velocity is higher than $5000 \mathrm{~m} / \mathrm{s}$. whereas, the FAG sample is moderately weathered because its wave velocity is between 3000$4000 \mathrm{~m} / \mathrm{s}$ range. This property was considerable from the obtained block samples.

If the uniaxial compressive strength (UCS) and slake-durability index (Id) of the ABS and CMM samples are considered, it will be understood that the UCS of these samples are obtained near each other whereas, their slake-durability indexes are different. This property is in live with the presence of abundant graphite and minerals that are not very hard in the CMM sample. Graphite is resistant in acidic solutions such as sulfuric acid and will increase slake-durability index.

Based on the durability assessments, the index of rock durability gives high durability for all samples. The weight loss-number of the cycles curve (Figure 4) is an exponential curve. This means that the weight loss at the initial cycles is higher than the end cycles. Also, maximum weight loss was obtained from the FAG sample whereas its minimum was detected in the CMM sample. It should be noted that the influence of $\mathrm{pH}$ on weight loss is indistinct, because the maximum 
weight loss for the HYD sample occurs in $\mathrm{pH}=5.5$, for the $\mathrm{ABS}$ sample occurs in $\mathrm{pH}=7.0$, for the $\mathrm{CMM}$ sample occurs in $\mathrm{pH}=4.0$ and for the FAG sample occurs in $\mathrm{pH}=4.0$. Furthermore, the minimum weight loss for the HYD sample occurs in $\mathrm{pH}=4.0$, for the $\mathrm{ABS}$ sample occurs in $\mathrm{pH}=2.0$, for the $\mathrm{CMM}$ sample occurs in $\mathrm{pH}=2.0$ and for the FAG sample occurs in $\mathrm{pH}=7.0$. After 15 cycles, maximum durability index was obtained from the CMM samples whereas the FAG samples indicated a minimum durability index. HYD and ABS samples had a middle range durability index. Therefore sensitivity of the FAG sample to chemical weathering is higher than the HYD, ABS and CMM samples.

Results of XRD analysis before and after slake-durability test indicated that the initial minerals in the fresh rock didn't change after 15 cycles of durability test and were not exchanged by clay minerals. This means that Hamedan hornfelsic rocks are nearly resistant under accelerated chemical weathering.

\section{Conclusion}

The following conclusions were reached from the observations and findings of the mineralogical, physical and durability properties and XRD analysis of the Hamedan hornfelsic rocks.

Metamorphic minerals of the studied hornfelsic rocks have greater density than other minerals and increase rock density. This property increases rock durability. On the other hand, presence of non- 
dissolved minerals such as graphite in rock, decreases UCS but increases the slake durability index.

Water absorption of rocks is affected by porosity. Therefore, on increase in the porosity value decreases rock durability. The computation of the physical properties indicates that the HYD and ABS samples have the highest dry density and the lowest porosity where in contrast the FAG samples have the lowest dry density and the highest porosity.

The index of rock durability gives high durability for all samples. The weight loss-number of cycles curve was an exponential curve. This means that weight loss at the initial cycles is higher than the end cycles. The evaluations of the durability values attained indicate that the FAG sample has the lowest and the CMM sample has the highest durability among all samples.

The initial minerals in fresh rock were durable after 15 cycles of the slake durability test. This result shows that the hornfelsic rocks of the study area are resistant under accelerated chemical weathering.

\section{Acknowledgements}

The authors would like to thank Dr. B. Rafiei for his help in the chemical analysis and XRD graphs discussion and Dr. F. Aliani and Mrs. R. Jafari for their help in the mineralogical studies of the samples. 


\section{References}

1. ASTM, "Standard test method for slake durability of shales and similar weak rocks (D4644)", Annual Book of ASTM Standards, vol. 4.08. ASTM, Philadelphia, PA (1990) 863-865.

2. Bell F.G., "Engineering geology", Blackwell Scientific Publications, London (1993).

3. Bell F.G., "Engineering properties of soils and rocks", Blackwell Science Ltd. (2000).

4. Bell F.G., Entwisle D.C., Culshaw M.G., "A geotechnnical survey of some Biritish coal measures mudstones, with particular emphasis on durability", Eng Geol 46 (1997) 115-129.

5. Dhakal G., Yoneda T., Kato M., Kaneko K., "Slake durability and mineralogical properties of some pyroclastic and sedimentary rocks", Engineering Geology 65 (2002) 31-45.

6. Dick J.C., Shakoor A., "Characterizing durability of mud rocks for slope stability purposes",Geol. Soc. Am., Rev. Eng. Geol. X, (1995) 121-130.

7. Erguler Z.A., "Field-based experimental determination of the weathering rates of the Cappadocian tuffs", Engineering Geology 105 (2009) 186199.

8. Franklin J.A., Chandra R., "The slake-durability test" Int. J. Rock Mech", And Min. Sci. 9 (1971) 325-341.

9. Ghobadi M.H., Momeni A.A., "Assessment of granitic rocks degradability susceptive to acid solutions in urban area", Environ Earth Sci. 64 (2011) 753-760. 
10. Gokceoglu C., Ulusay R., Sonmez H., "Factors affecting durability of selected weak and clay bearing rocks from Turkey, with particular emphasis on the influence of the number of drying and wetting cycles", Engineering Geology 57 (2000) 215-237.

11. Gupta V., Ahmed I., "The effect of $\mathrm{pH}$ of water and mineralogical properties on the slake durability (degradability) of different rocks from the Lesser Himalaya, India", Eng. Geo. 195 (2007) 79-87.

12. ISRM, "Suggested Methods for Determining Water Content, Porosity, Density, Absorption and Related Properties and Swelling and Slake-Durability Index Properties" (1981).

13. Lee S.Y., Kim S.J., Baik M.H., "Chemical weathering of granite under acid rainfall environment, Korea", Environ Geol. 55 (2008) 853862.

14. Oyama T., Chigira M., "Weathering rate of mudstone and tuff on old unlined tunnel walls", Engineering Geology 55 (1999) 15-27.

15. Rodrigues J.D., "Physical characterization and assessment of rock durability through index properties", NATO ASI Ser. E. Applied Sci. 200 (1991) 7-34.

16. Sajinkumar S.K., Anbazhagan S., Pradeepkumar A.P., Rani V.R., "Weathering and Landslide Occurrences in Parts of Western Ghats, Kerala", Jour. of the Geol. Soc. of India 78 (2011) 249-257.

17. Schiavon N., "Kaolinisation of granite in an urban environment", Environ Geol. 52 (2007) 399-407. 
18. Sims I., "Quality and durability of stone for construction", Q. J. Eng. Geol. 24 (1991) 67-73.

19. Topal T., Sozmen B., "Deterioration mechanisms of tuffs in Midas monument", Engineering Geology 68 (2003) 201-223.

20. Ulusay R., Sonmez H., "Factors affecting the durability of selected weak and clay bearing rocks from Turkey, with particular emphasis on the influence of the number of drying and wetting cycles", Engineering Geology 57 (2000) 215-237.

21. Yavuz A.B., "Deterioration of the volcanic kerb and pavement stones in a humid environment in the city centre of Izmir, Turkey", Environ Geol. 51 (2006) 211-227. 